\title{
An interregnum: masculinity and British fiction at the turn of the century ${ }^{34}$
}

\author{
Katarzyna Więckowska \\ Department of English \\ Nicolaus Copernicus University \\ klew[]umk.pl \\ Received March 2015; accepted June 2015; published Summer 2015.
}

\begin{abstract}
The article offers a reading of the representation of the masculinity crisis at the end of the $20^{\text {th }}$ century in selected British novels. The works by Irvine Welsh, Graham Swift, Niall Griffiths, and Ian McEwan are situated against the development of pro-feminist men's writing and masculinity studies, as well as the mythopoetic men's movement and Robert Bly's bestselling Iron John: A Book About Men (1990). The article foregrounds the sense of an impasse that permeates the novels and that echoes the general feeling of in-betweenness characteristic for the turn of the century.
\end{abstract}

Keywords: feminism; gender; masculinity; masculinity crisis; British fiction.

In 1990, John Bly, the leader of the mythopoetic men's movement, published Iron John: A Book About Men, the first book on men to become a bestseller (Messner 1997: 8). Addressed to all those concerned about the future of men, Iron John presented the 1980s and 1990s as a time of masculinity crisis when "the increasing emphasis [...] on the adult man's inadequacy" was accompanied by "the woman's increased awareness of her own interior emotional richness" (Bly 1990: 186). According to Bly, the end of the $20^{\text {th }}$ century was the period when women, encouraged by the feminist movement, were "coming out into activity" while men were "passing them going the other way, into passivity" (1990: 61), acquiring in the process a kind of "softness" that kept them at the stage of being boys and prevented them from becoming "real" men (1990: 180). Bly identified several causes of the increasing "softness" in men, in particular the growing independence of women, the absence of fathers, and, most importantly perhaps, the lack of adequate images of adult

\footnotetext{
${ }^{34}$ This article significantly draws on my Spectres of Men: Masculinity, Crisis and British Literature (2014), particularly on the last chapter.
} 
manhood in culture (1990: ix, 31). This lack of models to follow made finding new images for men a crucial and urgent task; accordingly, Bly advised men to return to some "olden" images of manhood, such as the figure of Iron John from the Grimm brothers' tale, in order to recover the "deep masculine,” to "bring the interior warriors back to life," and to re-discover "the Wild Man lying in every man” (1990: 146, 6).

Although Iron John focused on the situation of men in the late- $20^{\text {th }}$-century United States, its immense popularity and the spread of the wild men's movement testify to the fact that it addressed a wider and more globally experienced problem. Bly's book was followed by other publications, including Neil Lyndon's No More Sex War: The Failures of Feminism published in Britain in 1992, which presented men as seriously disadvantaged and pointed to the women's liberation movement as responsible for the general intolerance towards men, and Anthony Clare's On Men: Masculinity in Crisis (2000), which claimed that men were increasingly perceived as "redundant" and were (unjustly) portrayed as the main perpetrators of a number of social evils (2000: 4). Throughout the 1990s, there appeared numerous declarations that men were suffering from an acute crisis and that the late- $20^{\text {th }}$-century society and culture were undergoing an overall process of feminization, including the feminization of the public sphere and of work. The growth of consumerism in particular was seen as responsible for producing effeminate men, since, as Susan Faludi argued in Stiffed: The Betrayal of the American Man (1999), it led to the emergence of "ornamental culture" which defined manhood through appearances, thereby turning it into an image without any substance (2002: 605). The accounts of the crisis proliferated, documenting its appearance in various spheres of life in order either to "celebrate" it as the proof of the need to rebuild men's damaged sense of self and their decreased power or to interrogate naturalised notions of masculinity so as to deconstruct the mechanisms of patriarchal dominance (Archer 2004: 245). What these accounts shared, regardless of their stance, were the images of suffering and broken men in which national, class, or ethnic differences were transgressed in the universal and universalizing experience of male pain.

This article discusses selected novels published in Britain in the 1990s and 2000s in which images of men in crisis were used in order to explore male mythologies and to question rather than celebrate notions of masculine power. ${ }^{35}$ The protagonists of the books by Irvine Welsh, Niall Griffiths, Graham Swift, and Ian McEwan are men driven by the desire to change, but frequently

\footnotetext{
${ }^{35}$ The crisis is also the crisis of a certain model of national belonging at the time of devolution. Although I do not place the novels in the national context, it is worth mentioning that the connections between male "gender trouble" and national trouble have been analysed by a number of critics. For example, Berthold Schoene offers the general comment on Scottish fiction that "within the imperial framework of English-Scottish relations, the Scottish male is already feminized as a disempowered native (br)other” (1999: 134).
} 
immobilised by the sense of guilt or the impossibility to imagine the change. Featuring Welsh, Scottish, and English protagonists of various classes to record the fin-de-siècle masculinity crisis, the novels share the emphasis on the "broken" condition of contemporary men. While they may not offer any new model of manhood, these works explore some of the ways in which hegemonic masculinity has been constructed, highlighting the role literature has played in its making and demonstrating how it can contribute to its unmaking. By revisiting some "olden" images of manhood, they show their ongoing influence and indicate that, contrary to Bly's contention, "the battlefield" may not be "the warrior's" only "area of expertise and experience" (1990: 150), and that not all men may necessarily desire to be warriors. Documenting the growing feeling of dissatisfaction with a masculinity linked to power, oppression, and homosociality, they are texts of a crisis, the period described by Antonio Gramsci as the time of the interregnum, when "the old is dying and the new cannot be born" (1978: 276). In this article, they are approached as records of the interregnum, whose focus on suffering men is a necessary prerequisite for creating the space from which new masculinities may emerge.

The element uniting the various novels and the recurring trope in British fiction at the turn of the century is the battered and suffering male body, whose decomposition mirrors the contemporary state of crisis, but also allows for the deconstruction of masculine myths. Thus, the strong and strange protagonist of Irvine Welsh's Marabou Stork Nightmares (1995), Roy Strang, narrates his story in a state of coma after a suicide attempt, to which he was driven by the feeling of guilt for having participated in the rape of his school friend, Kirsty. A dead man lies at the centre of Graham Swift's Booker-prize winning Last Orders (1996), which depicts a group of men on their way to Margate to scatter the ashes of their friend, Jack. Detective Bruce Robinson in Welsh's Filth (1998) is a murderer, sexist, cross-dresser, and pornography and drug addict who suffers from a terrible skin rash, venereal disease, is literally being eaten from the inside by a tapeworm, and hangs himself at the end of the novel. Dead and mutilated bodies mark the retreat from Dunkirk, whose description forms the middle part of Ian McEwan's Atonement (2001), with the marching men "passing more bodies in the road, in the gutters and on the pavement, dozens of them, soldiers and civilians" (2001: 227). Finally, in Niall Griffiths's Kelly+Victor (2002), Kelly carves her name and that of her lover into his back, thus making him realise that he is "just meat" (2002: 107).

The images of suffering men make the crisis corporeal and demonstrate the bankruptcy of the old ideal which bound manhood with dominance, power, and emotional restraint. Interestingly, in many of the novels mentioned above the ideal of virility is linked with the literary images of manhood that depicted male physical fitness as reflecting a sound moral and spiritual stance. The mutilated bodies on the road from Dunkirk in McEwan's Atonement show the emptiness of the ideal of intellectual manliness which was propagated by the 
English public schools and universities in the first half of the $20^{\text {th }}$ century, but which did not prepare the young men for the real world of wars: it "revered the free, unruly spirits," the poets, who knew little about "surviving as a body of men" (McEwan 2001: 264). The model of the imperial adventurer and hunter of $19^{\text {th }}$-century British fiction for boys and men is ironically revived in Welsh's Marabou Stork Nightmares, which presents the comatose Roy dreaming about manly adventures in Africa. Accompanied by Sandy Jamieson, his best friend, "a former professional sportsman and an experienced hunter of man-eating beasts" (1997: 4), Roy is, like Alan Quatermain, the virile hunter, whose task is "to eradicate the scavenger-predator bird known as the Marabou Stork” (1997: 4). As the tragic fate of McEwan's and Welsh's protagonists demonstrates, neither the intellectual nor the adventurer are viable models of manhood. Additionally, the novels indicate that the gap separating the ideals of manhood from men's real life is not only unbridgeable but also selfdestructive, where the test of manhood in manly combat or adventure ends with the men's death.

Alongside the depiction of the old models of manhood as inadequate, the novels critique some more recent masculinity ideals such as the New Man or the Retributive Man that circulated at the end of the $20^{\text {th }}$ century. Emerging in the 1980s, these models have been described as representing different reactions to feminism and to masculinity crisis: while the New Man, aware of feminism and self-reflexive about masculinity, unsettled some mainstream assumptions about gender relations (Whannel 2002: 75-77), the Retributive Man presented a return to the traditional image of manhood based on violence and absence of women. Popularised by films such as Sylvester Stallone's Rambo (1982, 1985, 1988), the Retributive Man represented "virulent machismo" and "an idealised phallic masculinity" (Rutherford 1997: 31-32), and asserted his power through violent actions that were portrayed as heroic struggles. As Jonathan Rutherford argues, the Retributive Man was both a response to and a sign of masculinity crisis: he "confront[ed] a world gone soft, pacified by traitors and cowards, [and] dishonourable feminised men," and he distributed "just" punishment to all those who threatened his notions of manhood, honour, and national pride (1997: 28-20). In this hypermasculine world, the male body was put on display: strong, excessively muscular, and able to withstand pain, it was turned into a symbol of personal and national integrity, and of gender stability. Situated against this model, the bodies of the protagonists of end-of-the-century British fiction are not a source of strength, but a sign of crisis, where male heroism leads to self-inflicted pain and ultimately to selfdestruction. These are bodies consumed by guilt and in need of redemption, even if that redemption frequently leads to self-annihilation. 
A sense of guilt springing from the recognition of the violence inherent in hegemonic masculinity permeates many of the novels, and it is frequently accompanied by the conviction that neither redemption nor change is possible. In Welsh's Marabou Stork Nightmares, for example, the acquitted rapist Roy attempts to change his life and to turn himself into a New Man. His Ecstasy-induced transformation into a better man takes place during the "Zero Tolerance Campaign" against male violence against women and children, ${ }^{36}$ thereby reinforcing the link between masculinity and aggression. Roy's transformation, however, cannot be successful, which is made explicit by the revelation that the marabou stork, the predator "detested and despised by human beings" (1997: 55), is Roy himself. The novel turns the stork into "the personification of all [...] badness," so that killing him would "kill the badness in [Roy]" and make him "ready to come out of here, to wake up, to take [his] place in society" (1997: 9-10). As the protagonist realises, the stork cannot be killed, although it may be forced "into a temporary migration" (1997: 55). Accordingly, Roy cannot "save" himself, but he is "delivered" out of the badness by his victim, Kirsty, who violently castrates him in the final chapter of the book, meaningfully entitled "The paths of self-deliverance." A similar sense of impasse and desire for self-destruction is present in Filth, where the despicable detective Bruce Robinson grows "softer" as the worm inside him - his "conscience" - grows stronger. At the end of the novel, the detective prepares his own death as a revenge on his ex-wife, but ends up accidently killed by his daughter, thereby burdening her with the legacy of violence and trauma. The pattern of perpetuated violence returns in Griffiths's Kelly+Victor, where Kelly, a professional dominatrix, strangles Victor at the novel's finale, thereby fulfilling her desire to "mend" and "fix" him, and to "glue him back together" (2002: 307). For Victor, death is a source of intense sexual pleasure and a moment of fullness of being when he not only finally sees "the light" he has always longed for, but actually becomes the light (2002: 157). Significantly, the "light" that the dying Victor turns into is linked with the memory of his birth, thus suggesting that the need for (masculine) re-birth inevitably courts the danger of death.

The novels by Griffiths and Welsh present the dominant model of masculinity as damaging and self-destructive, and as what must be radically re-structured. The books mirror the sense of masculinity crisis that permeated the end of the $20^{\text {th }}$ century as well as reflect the themes which dominated the studies of masculinity and which both depicted and reinforced the sense of gender impasse. Already in the 1970s, the relation between masculinity and power, and its negative influence on men were critiqued by a number of pro-feminist men's groups, including the Men's Free Press Collective of Achilles Heel who claimed that "our power in society as men not only oppresses women but also impris-

\footnotetext{
${ }^{36}$ The "Zero Tolerance Campaign” was organized in Edinburgh in the early 1990s.
} 
ons us in a deadening masculinity which cripples all our relationships - with each other, with women and with ourselves" (2004: 85). ${ }^{37}$ The writings by profeminist men in the early 1970s emphasised the costs of masculinity, and in the mid-1970s turned to examine the privileges and power of men in patriarchal society (Messner 1997: 50), thereby setting the ground for masculinity studies, or studies of men and masculinities, which by the 1990s had become an independent field of study. Throughout the late 1980s and 1990s, studies that presented men and masculinity as a problem proliferated in Britain, and numerous books were published in which masculinity was "discovered, rediscovered, theorised, constructed, deconstructed, dislocated, unwrapped, unmasked, understood, embodied, fashioned, moulded, changed and put in perspective" (Whannel 2002: 20), and which produced various responses such as the New Man or the anti-feminist writings by Lyndon and Clare. In effect, a growing number of critics in the 1990s began to conceptualise masculinity as by definition in perpetual crisis (Wiegman 2002: 32), and by the end of the decade "masculinity as crisis" had become the "regulatory fiction" of masculinity studies and its "proscribed critical refrain" (Traister 2000: 297, 281). The focus on crisis effectively interrogated masculine norms, but it also produced a sense of suspension between progressive change and conservative backlash, leading to an impasse in which, as the endings of the novels show, it was difficult to imagine a model for the man of the future.

While Welsh's and Griffiths's novels stress the men's need to change, they represent the transformation as hardly possible. In contrast, Graham Swift's Last Orders depicts a more accommodating relation to the legacy of masculinity models. The book describes the journey of a group of men to scatter the ashes of Jack Arthur Dodd, their friend and the strong patriarch who held them all together, but whose passing away liberated them from following the old patterns. Jack's death opens for the men the chance to change and to reform their lives through re-establishing the broken relations with women, their daughters and lovers. The complex relations between the old and new models of masculinity, as well as the impossibility to fully abandon the past are signalled by the novel's title, where, as Emma Parker argues, the "last orders" are simultaneously a reference to the male comradeship of the pub and to a world in which "last orders have metaphorically been called for masculinity” (2003: 89). Fulfilling their friend's last wish, the men scatter his ashes, carefully removing them from their hands and making sure that "Jack don't stick to us” (Swift 1996: 293), thereby metaphorically shedding their old skins and moving towards a different but unspecified kind of identity and manhood. While the novel promises the transformation of the men, it ends with the acknowledgment that any new model of manhood is anchored in the past

\footnotetext{
${ }^{37}$ Some men's accounts defined masculinity in opposition to humanity and justice. For example, Jack Sawyer in the United States called for changing men in order to terminate "the dehumanization of being (or trying to be) a master" (2004: 26).
} 
and that the masculine legacy must be continued, although in different ways, since the ash, "the Jack who once walked around [...] is whirled away by the wind till the ash becomes wind and the wind becomes Jack what we're made of' (Swift 1996: 295; my emphasis).

Like Swift's Last Orders, Ian McEwan's Sweet Tooth (2012) suggests a possibility of terminating the masculinity crisis and of moving on to construct the relations between men and women anew, without, however, specifying their character. Set in the 1970s, the time of the Cold War and of the women's liberation movement, the novel recasts the late- $20^{\text {th }}$-century crisis by returning to its alleged origin and by placing it in the larger socio-political context. The protagonist of the novel is Serena Frome, a secret service agent sent to watch over a young writer, Thomas Haley, and to convince him to support the Western cause in his work. The undercover operation is codenamed "Sweet Tooth," which is also the title of the record the writer decides to secretly keep when he accidently discovers Serena's mission and which, as it turns out at the end of the book, is the manuscript of the novel. Foregrounding espionage, deception, and doubling, the text presents the relations between the man and the woman as "too mired in deceit" but also as "too entwined in mutual surveillance to let each other go" (McEwan 2012). Haley describes the record of his surveillance of the woman spying him as "hardly an apologia" but "an indictment of [them] both", as well as an exercise in gender-bending, since in order to write about the woman, he had to become her: as he states, "I had to get out of my skin and into yours. I needed to be translated, to be a transvestite, to shoehorn myself into your skirts and high heels (...). Then start talking, as you" (McEwan 2012). The novel ends with Serena reading the manuscript by Haley, who leaves it up to her to decide what to do with the text and whether to continue their relationship. McEwan's book ends with a promise of transformation, making the woman responsible for its course; like Swift's Last Orders, it points to a movement beyond the de-construction of hegemonic masculinity towards the construction of new, although not innocent and as yet unknown images of men and women.

The turn of the century crisis of masculinity produced a sense of uncertainty and a variety of scripts for the future, with some critics suggesting the possibility of a post-gender or post-patriarchal world, and others writing about the emergence of transpatriarchies, or global patriarchal systems. ${ }^{38}$ Describing a crisis, Gramsci pointed to its ambivalent status as the time when the "restoration of the old (...) can be ruled out - yet not in an absolute sense" (1978: 276). While the books by Griffiths and Welsh depict the turn of the century as the period when "the old is dying and the new cannot be born" (Gramsci 1978: 276), the endings of Swift's and McEwan's novels herald the birth of new

\footnotetext{
${ }^{38}$ For a discussion of transpatriarchy, see Jeff Hearn’s "From Masculinities Back to Men: Tracing Diverse Psychological, Social and Political Threads” (2006).
} 
models of manhood, but refuse to describe them. In effect, the texts reinforce the sense of continuing transition and of an interregnum that echoes the contemporary feeling of in-betweenness of a period which "moves for the sake of moving, attempts in spite of its inevitable failure," and which "seeks forever for a truth that it never expects to find” (Vermeulen and Akker 2010).

\section{References}

Archer, Louise. 2004. 'Muslim Brothers, Black Lads, Traditional Asians': British Muslim Young Men's Constructions of Race, Religion and Masculinity. Peter F. Murphy, ed. Feminism and Masculinities: 244-254. New York: Oxford University Press.

Bly, Robert. 1990. Iron John: A Book About Men. Reading, MA.: Addison Wesley.

Clare, Anthony. 2000. On Men: Masculinity in Crisis. London: Chatto \& Windus.

Faludi, Susan. 2002. Stiffed: The Betrayal of the American Man. New York: Perennial.

Gramsci, Antonio. 1978. Selections from the Prison Notebooks of Antonio Gramsci. Eds. Quintin Hoare and Geoffrey Nowell Smith. London: Lawrence \& Wishart.

Griffiths, Niall. 2002. Kelly+Victor. London: Jonathan Cape.

Hearn, Jeff. 2006. From Masculinities Back to Men: Tracing Diverse Psychological, Social and Political Threads. The Psychology of Women Section Review, 8(1): 38-52.

Lyndon, Neil. 1992. No More Sex War: The Failures of Feminism. London: SinclairStevenson.

McEwan, Ian. 2001. Atonement. London: Jonathan Cape.

McEwan, Ian. 2012. Sweet Tooth. Toronto: Alfred A. Knopf. Ebook.

Men's Free Press Collective [of Achilles Heel]. 2004. Hopes and Dreams: Creating a Men's Politics. Peter F. Murphy, ed. Feminism and Masculinities: 80-92. New York: Oxford University Press.

Messner, Michael A. 1997. Politics of Masculinities: Men in Movements. California: Sage.

Parker, Emma. 2003. No Man's Land: Masculinity and Englishness in Graham Swift's Last Orders. Daniel Lea and Berthold Schoene, eds. Posting the Male: Masculinities in Post-war and Contemporary British Literature: 89-104. Amsterdam - New York, NY: Rodopi.

Rutherford, Jonathan. 1997. Forever England: Reflections on Race, Masculinity and Empire. London: Lawrence \& Wishart.

Sawyer, Jack. 2004. On Male Liberation. Peter F. Murphy, ed. Feminism and Masculinities: 25-27. New York: Oxford University Press.

Schoene-Harwood, Berthold. 1999. Dams Burst: Devolving Gender in Iain Banks's The Wasp Factory. Ariel: A Review of International English Literature 30:131-148.

Swift, Graham. 1996. Last Orders. London: Picador. 
Traister, Bruce. 2000. Academic Viagra: The Rise of American Masculinity Studies. American Quarterly, 52(2): 274-304.

Vermeulen, Timotheus, and Robin van den Akker. 2010. Notes on Metamodernism. Journal of Aesthetics \& Culture, Vol. 2, DOI: 10.3402/jac.v2i0.5677.

Welsh, Irvine. 1997. Marabou Stork Nightmares. New York, London: W.W. Norton and Company.

Welsh, Irvine. 1998. Filth. London: Jonathan Cape.

Whannel, Garry. 2002. Media Sport Stars: Masculinities and Moralities. London: Routledge.

Wiegman, Robyn. 2002. Unmaking: Men and Masculinity in Feminist Theory. Judith Kegan Gardiner, ed. Masculinity Studies and Feminist Theory: New Directions: 3159. New York: Columbia University Press.

Więckowska, Katarzyna. 2014. Spectres of Men: Masculinity, Crisis, and British Literature. Toruń: Nicolaus Copernicus University Press. 